\begin{tabular}{|l|l|l||}
\hline \multicolumn{2}{|c|}{ PublisherInfo } \\
\hline \hline PublisherName & $:$ & BioMed Central \\
\hline \hline PublisherLocation & $:$ & London \\
\hline \hline PublisherImprintName & $:$ & BioMed Central \\
\hline \hline
\end{tabular}

\title{
Suppression of arthritis by metallothionein
}

\begin{tabular}{|l|l|l||}
\hline \multicolumn{2}{|c|}{ ArticleInfo } \\
\hline \hline ArticleID & $:$ & 253 \\
\hline \hline ArticleDOI & $:$ & $10.1186 /$ ar-2002-78052 \\
\hline \hline ArticleCitationID & $:$ & 78052 \\
\hline \hline ArticleSequenceNumber & $:$ & 6 \\
\hline \hline ArticleCategory & $:$ & Paper Report \\
\hline \hline ArticleFirstPage & $:$ & 1 \\
\hline \hline ArticleLastPage & $:$ & 3 \\
\hline \hline & & RegistrationDate : 2002-9-26 \\
ArticleHistory & $:$ & Received \\
& $:$ 2002-9-26 \\
\hline \hline ArticleCopyright & $:$ & Biomed Central Ltd2002 \\
\hline \hline ArticleGrants & $:$ & \\
\hline \hline ArticleContext & $:$ & 130754411 \\
\hline \hline
\end{tabular}


Aff1 Imperial College, London, UK

\section{Keywords}

Collagen-induced arthritis, metallothionein, TGF- $\beta$

\section{Context}

Metallothioneins are a family of stress response proteins that sequester toxicants, thereby protecting cellular components. Extracellular metallothionein has been shown to have functional effects on macrophages and T and B lymphocytes. Disruption of metallothionein genes or treatment with monoclonal antibodies to metallothionein result in an enhanced humoral response to antigen challenge, indicating that metallothionein may play a role in suppressing immune function. Elevated levels of metallothionein have been observed in rheumatoid arthritis. However, these levels fall with disease progression, but are enhanced with cortisone treatment, correlating with clinical improvement. In this study the authors have tested the efficacy of metallothionein in treating collagen-induced murine arthritis.

\section{Significant findings}

Daily injections of metallothionein I and II proteins dramatically reduced the incidence and severity of disease in mice with established arthritis. Histological analysis demonstrated that metallothionein treatment significantly increased the number of unaffected joints, while reducing the severity of disease in affected joints. Reverse transcriptase-polymerase chain reaction (RT-PCR) analysis demonstrated that elevated levels of tumor necrosis factor (TNF)- $\alpha$ and cycloxygenase- 2 in arthritic joints following booster immunisations were reduced in metallothionein-treated mice. In addition metallothionein inhibited the proliferation of collagen-specific lymphocytes upon in vitrostimulation with collagen, and induced transforming growth factor (TGF)- $\beta$ production by these cells.

\section{Comments}


Previous studies using metallothionein-deficient or transgenic mice have demonstrated that metallothionein plays a protective role in autoimmune diseases such as experimental autoimmune encephalomyelitis and diabetes. In the present study metallothionein administration prevents disease progression in arthritic mice and suppresses established disease. The authors suggest that metallothionein acts by stimulating the production of the anti-inflammatory cytokine TGF- $\beta$ and by inhibiting the proliferation of specific lymphocyte populations. Whether the effects of metallothionein are related to its radical scavenging capabilities was not investigated. If well tolerated, inducers of metallothionein expression would be appropriate targets for therapeutic development.

\section{Methods}

ELISA, histopathological analysis, proliferation assays, RT-PCR

\section{References}

1. Youn J, Hwang S-H, Ryoo Z-Y, Lynes MA, Paik D-J, Chung H-S, Kim H-Y: Metallothionein suppresses collagen-induced arthritis via induction of TGF- $\beta$ and down-regulation of proinflammatory mediators. Clin Exp Immunol. 2002, 129(2): 232-240. 